\title{
IMPROVING STUDENTS' VOCABULARY MASTERY USING ENGLISH SONG
}

\author{
Intan Permata Sari ${ }^{1}$, Elva Elvinna Asahra ${ }^{2}$, Yana ${ }^{3}$ \\ ${ }^{1}$ IKIP Siliwangi \\ ${ }^{2}$ IKIP Siliwangi \\ ${ }^{3}$ IKIP Siliwangi \\ ${ }^{1}$ intantanpermata@yahoo.com, ${ }^{2}$ elvinnaelva@gmail.com, ${ }^{3}$ yanaenglish.edu@gmail.com
}

\begin{abstract}
This research is a Classroom Research Action. The research aims to improve the tenth grade students of SMK Wirasaba Karawang in mastering vocabulary using English songs. Songs can be trusted to help remember vocabulary and used the songs are interested in learning English. Memorizing song can be used to develop English vocabulary mastery so that the purpose of learning English as a communication tool can be achieved optimally. It can be seen from the students' score on vocabulary test which increased from three vocabulary tests given in the Cycle I and Cycle II. In the students' achievement Cycle I was 67.33 and Cycle II was 83.7. It can be concluded that songs have a significant impact on improving students' vocabulary mastery.
\end{abstract}

Keywords: English song, vocabulary mastery, CAR

\section{INTRODUCTION}

Teaching vocabulary is a fairly difficult process for students and teachers, a process that requires many ways from both parties so that the teacher can convey it well and students can receive it well. In Indonesia, English as a foreign language has a prominent role in an international communication, especially in the frame of improving a competition force among nations (Suprijadi, 2014). Vocabulary is one aspect of language that must be considered. It is the main aspects of acquiring and understanding language. Vocabulary is generically defined as the knowledge of words and word meanings. More specifically, we use vocabulary to refer to the kind of words that students must know to read increasingly demanding text with comprehension (Hiebert, 2005) as cited in Nurdiansyah, Asyid, \& Parmawati. (2019). There are many ways that students can obtain and learn foreign languages for example by using songs. Memorizing songs is believed that not only makes students interested but songs can also help them learn vocabulary more easily (Dewi, 2013).

Songs can be a good learning resource for English classes. Those are because English songs are already known enough by some students. The class also can be fun and joyful learning. It needs not too much time or meeting to do (Agustina, 2016). Teachers are required to be creative in class so that children become more interested in English. Therefore, their interest in English will be an important foundation to achieve more satisfying English skills.

In this research, researchers applied to students by memorizing English songs to teach vocabulary as the right technique to solve students' vocabulary mastery. The technique of memorizing English songs is also a technique where students must memorize English songs chosen by the teacher based on the syllabus used by SMK Wirasaba Karawang. 
The use of English songs in class can help bring effective learning by providing fun learning classes, reducing student anxiety, fostering students' interest in learning and improving students' motivation to learn foreign language. The popularity of pop songs ensures that they are very potential to motivate students to learn language (Limbong, 2012). So that students will be more interested in learning through English songs that are considered fun and not boring. Some vocabulary that must be mastered by students through memorizing songs, namely the words that are in the lyrics of the song.

Memorizing English songs is the way that allows students to repeat and remember the vocabulary. In addition, although most students regard learning by listening to English songs as entertainment, they also learn spontaneously and unconsciously, which is much more fun and efficient way to increase language awareness better than mechanically memorizing tedious course-books of vocabulary and grammar (Shen, 2003). Thus, memorizing English songs can be considered useful to learn vocabulary easily.

In the field are often encountered teachers who complain about experiencing difficulty in organizing classes, for example, because students are too active to move and play games in the classroom, difficult to organize, easily to get bored and lost motivation as well as concentration, disputes with his friend. In the other hand is often also encountered students feel less happy and deep spirit learn English because of the way of teacher explanation too structuralist.

Lack of media used. Usually, the teacher only explains/gives an oral description of a state/shape/place. So students can only imagine without looking directly at the form/situation, so they are difficult to understand and understand the intentions conveyed by the teacher. The low memory of students, not because of factors from students only. But this problem is also due to the process of learning activities of students who are less active, lack of interest in learning and don't pay attention to the teacher. Based on observations made during the implementation of learning, researchers still find that the application of learning is still not optimal and there are still many shortcomings in the implementation of learning. But there are also some students who are less enthusiastic because of differences in the characteristics of students.

\section{Vocabulary Mastery}

According to (Cameron, 2001), the aspects of vocabulary mastery include pronunciation, spelling, and meaning. Vocabulary is a familiar collection of words that we often hear in language to a person. So the vocabulary is word storage and uses as a tool to communicate. The more vocabulary that is familiar or often heard in the brain, the faster it will remember.

Vocabulary is one of the most important things in learning foreign languages, for example learning English. Vocabulary also has an important role in language learning. Someone that wants to communicate will be very difficult when he tried to translate it to English because he or she doesn't have enough vocabulary storage. The same case will happen when we try to listen to what people say. It will be difficult if we haven't ever heard about a word that he or she says. Without a lot of vocabulary, it's impossible to use English correctly and clearly (Bridge \& Burton, 1982). It is proved that vocabulary is very important when we learn a foreign language, especially English language which has a variety of vocabulary.

\section{Definition of Song}

Songs as learning media that can make learning fun and not boring. Song can balance intellectual and emotional intelligence so that they will provide good results for students. Songs 
can stimulate brain function, the meaning of songs provide stimulation for the growth of memory functions to learn vocabulary, language, listening and speaking. The learners need a way of teaching that is practical and fun teaching methods so that they can integrate themselves into English, for example singing English songs can make students integrated into English (Gushendra, 2017).

There are several benefits of using songs in language learning. First of all, they can encourage students to use English. Furthermore, listening to English songs helps students support words and meanings more easily the compilation of songs is supported by images and actions. Finally, songs can stimulate a positive emotional attitude toward language learning.

\section{METHOD}

\section{Classroom Action Research (CAR)}

In this research, the researchers used CAR. According to (Cameron-Jone, 1983) action research is research conducted by researchers with a view to improve the professional practice of researchers and understand it better. There are four stages of each cycle, they are: (1) the planning of the action, (2) the implementation of the action, (3) classroom observation and (4) reflecting of the action (Kemmis \& McTaggart, 1988). This research was conducted at SMK Wirasaba Karawang, involving 30 students with 20 females and 10 males of class X-Nursing in academic year of 2018/2019.

\section{Planning}

In the planning stage, the researchers prepared the research instruments, designed the lesson plans, selected the English songs, set the criteria of success and made the research schedule.

\section{Implementing}

In this stage, the researchers act as a teacher who implements the action, while the classroom English teacher takes a role as an observer who observes the action implementation.

\section{Cycle 1}

In this section, the researcher applied the treatment to the students based on the lesson plan prepared through song memorization. There are steps made in implementing the English songs memorization technique. The steps are: (1) playing the song video and/or singing the song by the teacher, (2) ask the students to do listening exercise given in the students' worksheet and discuss the answer together, (3) lead the students to sing the song line by line until the students could memorize the song and could sing independently, and (4) lead the students to sing the song together with some fun supportive activities.

\section{a. Meeting 1}

Firstly, the researcher asked the students about their favorite English song. The song played first was Hero by Mariah Carey. It was played 3 times. First playing aimed the students can enjoy music first. After that, the teacher delivered the sheets which contain blank word/ phrase and asked students to fill it. Then the students have to collect the sheets. After that, the teacher delivered the second sheets. The second song was Count on Me by Connie Talbot. Then, they have to fill the blank sheet again. They had to collect again. The last song was I have a dream by Westlife. It was done by the same treatment.

b. $\quad$ Meeting 2 
In the 2nd meeting, the teacher gave a different song to the students. In this meeting, the material was about comparison and contrast. Here, the same treatment as meeting 1 was applied to the students. The songs that the teacher chose was Flashlight by Jessie J and Heal The World by Michael Jackson. In the last 15 minutes, the students were asked to do posttest to know their improvement in vocabulary.

\section{Cycle 2}

\section{a. Meeting 1}

In this meeting, the students were taught about passive voice. Here, the teacher tried to change the treatment. In this section, the teacher gave the explanation about the material first. After that, the teacher played the song. The song played in many times (up to the students' ability). The teacher also gave blank sheet to the students. And the students had to answer the vocabularies. While their doing the filling, the teacher also made a gesture of the vocab they needed. For example, they try to guest the word "run", so the teacher had to act "run" in front of the students. In the last minutes, they had to collect the sheets. The song would be played were She will be loved by Maroon 5 and Someone like you by Adelle.

\section{b. $\quad$ Meeting 2}

In this meeting, the teacher gave the same treatment to the students, as the previous meeting. In this meeting, the teacher discussed parallel structure. The songs played were Beautiful in White by Westlife and Life Is Worth Living by Justin Bieber.

\section{Observing}

In this study, the observation of students' new vocabulary mastery was conducted to obtain data and to find out about how well the implementation of memorizing English songs techniques could achieve the research objectives. In this stage, researchers collected data related to the implementation of actions using several instruments. The first is the observation checklist that is filled by the observer. The second is the field notes made by the teacher. Those two instruments were used to gain the data related to the students' participation. The third is the result of vocabulary tests conducted by students at the end of each cycle, it aims to obtain data about student vocabulary mastery. The fourth is the result of a questionnaire given to students at the end of the study, which aims to find information about student responses to the use of techniques to memorize English songs.

\section{Reflection}

In this stage, the researchers reflects the data from the action with activities reflecting the implementation of the cycle obtained through observations and the implementation of techniques to memorize English-language songs in the teaching-learning process. The results are compared with the designed success criteria. The criteria for success were achieved. If it failed, the researcher will continue the study to the next cycle.

\section{RESULTS AND DISCUSSION}

\section{Results}

The result of the research showed that there was improvement from Cyvle I to Cycle II in the students' participation in intriduction, discussion and practice. In the students' achievement Cycle I was 67.33, the average score of the Cycle II was 83.7 
Table 1.Test Results in Cycle I

Cycle I

\begin{tabular}{rlr}
\hline No & Explanations & Scores \\
\hline 1 & The highest score & 84 \\
\hline 2 & The lowest score & 51 \\
\hline 3 & The average score & 67.33 \\
\hline
\end{tabular}

Table 2.Test Results in Cycle II

\begin{tabular}{rlr}
\multicolumn{3}{c}{ Cycle II } \\
\hline No & Explanations & Scores \\
\hline 1 & The highest score & 100 \\
\hline 2 & The lowest score & 70 \\
\hline 3 & The average score & 83,7 \\
\hline
\end{tabular}

Based on the results obtained on student learning outcomes, student activities and teacher activities in cycle II showed a significant increase due to the use of songs.

\section{Discussion}

This study aims to improve students' vocabulary mastery by using English songs. Through two cycles, the learning process is carried out and runs well in tenth grade students of SMK Wirasaba Karawang. Based on the scores obtained, in cycle II it has reached the target score. Therefore researchers will not continue to cycle III. It is proven that using this method can improve students' vocabulary mastery.

\section{CONCLUSION}

There are some conclusions drawn based on the data above. First, memorizing English songs can be considered as the right technique to improve students' vocabulary mastery, especially students of class X-K in SMK Wirasaba Karawang. This can be seen from the scores of students on the vocabulary test which increased from the three vocabulary tests given in the preliminary study, Cycle I, and Cycle II. Second, from the revised teaching strategy in Cycle II, it was found that the technique of memorizing English songs would be more promising in helping students' vocabulary mastery problems. Third, memorizing English songs can be a good technical choice in building a crowded classroom atmosphere to generate students' participation in teaching and learning activities. This is because, from the observation checklist, it was shown that the students could actively participate in the teaching and learning activity that was conducted by using English songs memorization. Fourth, the active participation of the students in learning shows their motivation that would be able to build their enthusiasm in learning. Thus, it could be seen from the results that memorizing English songs can be a good technical choice in teaching and learning vocabulary. They stated that memorizing English songs is a very interesting teaching technique to be used because the material of English songs are fun and easy to be followed.

\section{ACKNOWLEDGMENTS}

Alhamdulillahirabbil'alamin, thanks to Allah SWT who has enabled to finish this paper. Peace and salutations are always for Rasulullah SAW. Thanks to family and our lecturer during finishing this article. 


\section{REFERENCES}

Agustina, R. K. (2016). Mastering English Vocabulary Skill by Using Song to The Second Semester Students' of Accountancy Department in Hasyim Asy'ari University of Tebuireng Jombang. Ed-Humanistics: Jurnal Ilmu Pendidikan, 1(2).

Bridge, C. A., \& Burton, B. (1982). Teaching Sight Vocabulary Through Patterned Language Materials. New Inquiries in Reading Research and Instruction, 119-123.

Cameron-Jone, M. (1983). A Researching Profession? The Growth of Classroom Action Research. Scotland: Moray house College of Education.

Cameron, L. (2001). Teaching languages to young learners. Ernst Klett Sprachen.

Dewi, N. P. (2013). Using English Song Memorization Technique to Improve The Seventh Graders' Mastery of Vocabulary. Jurnal Online Universitas Negeri Malang, (January 2013), 1-12.

Gushendra, R. (2017). An Experimental Study : Improving Students' Vocabulary Mastery by Using English Songs. Indonesian Journal of Integrated English Language Teaching, 3(1), 53-64.

Kemmis, S., \& McTaggart, R. (1988). The Action Research Planner, 3rd. Victoria: Deakin University.

Limbong, R. (2012). Enriching Students 'Vocabulary Using English Pop Songs. Journal of English Teaching, 57, 223-237.

Nurdiansyah, D. M. R., Asyid, S. A., \& Parmawati, A. (2019). Using Color Coding To Improve Students'english Vocabulary Ability. Project (Professional Journal Of English Education), 2(3), 358-363.

Shen, C. (2003). Using English Songs : an Enjoyable and Effective Approach to ELT. English Language Teaching, 2(1), 88-94.

Suprijadi, D. (2014). Method to Post-method Pedagogy Administered by a Classroom Teacher in the Teaching of English, 8, 40-61. 